\title{
MOTIVASI BERPRESTASI DAN HASIL BELAJAR IPS DALAM PEMBELAJARAN DENGAN MODEL PEMBELAJARAN ACCELERATED LEARNING BERBASIS PETA KONSEP
}

\author{
I.P. Suardipa ${ }^{1}$, I.W. Lasmawan ${ }^{2}$, N.K. Suarni ${ }^{3}$ \\ ${ }^{1,2,3}$ Program Studi Pendidikan Dasar, Program Pascasarjana, Universitas Pendidikan Ganesha \\ Singaraja, Indonesia \\ e-mail: putu.suardipa@pasca.undiksha.ac.id ${ }^{1}$, lasmawan@pasca.undiksha.ac.id ${ }^{2}$, \\ tut_arni@yahoo.com ${ }^{3}$
}

\begin{abstract}
ABSTRAK
Penelitian ini bertujuan untuk mengetahui besarnya pengaruh model pembelajaran terhadap motivasi berprestasi dan hasil belajar IPS. Model pembelajaran yang diterapkan adalah Model Accelerated Learning berbasis Peta Konsep. Penelitian ini adalah penelitian eksperimen semu dengan populasi siswa kelas V SD KalibukbukBuleleng yang berjumlah 148 siswa dan sampel penelitian berjumlah 74 siswa. Data dianalisis dengan menggunakan MANOVA. Hasil penelitian menunjukkan: (1) terdapat perbedaan yang signifikan antara motivasi berprestasi antara siswa yang mengikuti Model Accelerated Learning berbasis Peta Konsep dengan siswa yang mengikuti Model Konvensional pada siswa kelas V di SD Kalibukbuk ( F = 7,345; p < $0,05)$, (2) terdapat perbedaan yang signifikan antara motivasi berprestasi dalam pembelajaran IPS antara siswa yang mengikuti Model Accelerated Learning berbasis Peta Konsep dengan siswa yang mengikuti Model Pembelajaran Konvensional pada siswa kelas V di SD Kalibukbuk ( $F=17,580$; $p<0,05)$, dan (3) Secara simultan motivasi berprestasi dan hasil belajar IPS antara siswa yang mengikuti Model Pembelajaran Accelerated Learning berbasis Peta Konsep secara signifikan lebih baik daripada siswa yang mengikuti Model Pembelajaran Konvensional $(\mathrm{F}=12.006$; $\mathrm{p}<$ $0,05)$.
\end{abstract}

Kata Kunci: Model accelerated learning berbasis Peta Konsep, motivasi berprestasi, hasil belajar, IPS.

\begin{abstract}
This research aims at investigating the effect of concept mapping based accelerated learning on achievement motivation and social studies learning achievement. The learning model used was concept mapping based accelerated learning. This was a quasi experiment with the population of 148 fifth grade students of elementary school in Kalibukbuk, Buleleng and the sample of 74 students. Data were analyzed using MANOVA. The results of the research show: (1) there is a significant difference of achievement motivation between students following concept mapping based accelerated learning model and those following conventional learning model of the fifth grade students of Kalibukbuk elementary school ( $F=7,345 ; p<0,05)$, (2) there is a significant difference of achievement motivation between students following concept mapping based accelerated learning model and those following conventional learning model of the fifth grade students of Kalibukbuk elementary school ( $F=17,580 ; p<0,05)$, (3) simultaneously, achievement motivation and social science learning achievement of students following concept mapping based accelerated learning is better than those following conventional learning model $(\mathrm{F}=12.006 ; \mathrm{p}<0,05)$.
\end{abstract}

Keywords: Concept Mapping Based Accelerated Learning Model, Achievement

Motivation, Learning Achievement, Social Studies 


\section{PENDAHULUAN}

Pendidikan merupakan suatu yang integral dan utama dalam konteks pembangunan bangsa dan negara. Pendidikan adalah suatu proses berkelanjutan untuk membantu manusia agar dapat mengeksplor potensi yang ada pada dirinya, untuk mampu menghadapi perubahan zaman yang menuntut mereka untuk berpikir logis, sistematik, kritis, cerdas, kreatif, terbuka, jujur dan mempunyai rasa ingin tahu yang tinggi dalam mencapai kehidupan yang holistis.

Undang-Undang No. 20 Tahun 2003 tentang SISDIKNAS, dapat dipahami bahwa secara formal sistem pendidikan Indonesia diarahkan pada tercapainya cita-cita pendidikan yang ideal dalam rangka mewujudkan peradaban bangsa Indonesia yang bermartabat. Untuk tercapainya cita-cita pendidikan yang ideal, pemerintah telah berupaya mengurangi adanya sekulerisme pendidikan (pendidikan yang lebih mementingkan materialistis dengan mengabaikan agama dan kerohanian) yang ada sebagaimana terungkap dalam UU No.20/2003 tentang SISDIKNAS pasal 4 ayat 1 yang menyebutkan, "Pendidikan nasional bertujuan membentuk manusia yang beriman dan bertakwa kepada Tuhan Yang Maha Esa, berakhlak dan berbudi mulia, sehat, berilmu, cakap, serta menjadi warga negara yang demokratis dan bertanggungjawab terhadap kesejahteraan masyarakat dan tanah air". Maka dari itu, pendidikan yang baik akan menjadi acuan tingkat perkembangan suatu bangsa.

Kurve perkembangan suatu bangsa juga ditentukan oleh unsur-unsur kemajuan dan eksplorasi pendidikannya. Peran utama yang melakoni pendidikan diantaranya adalah guru, siswa, sarana dan prasarana pendidikan maupun kebijakan yang telah ditetapkan pemerintah dalam bidang pendidikan. Unsur pendidikan yang sangat berperan penting dalam proses perkembangan pendidikan yaitu guru. Salah satu komponen penting dalam pendidikan, yang dapat mewujudkan tujuan nasional adalah guru. Guru dalam konteks pendidikan sebagai ujung tombak dalam meningkatkan mutu pendidikan. Guru mempunyai peranan yang besar dan strategis, dimana guru berada pada barisan terdepan dalam pelaksanaan pendidikan. Berbagai upaya telah dilakukan oleh pemerintah untuk meningkatkan mutu dan kualitas pendidikan, seperti dengan melakukan penyempurnaan kurikulum, melakukan musyawarah guru mata pelajaran (MGMP), penataran kinerja guru, hingga proyek peningkatan kualifikasi guru. Namun hal tersebut belum sepenuhnya berhasil, terbukti dilapangan masih banyak sekolah yang mengalami permasalahan dalam proses pendidikan khususnya dalam proses pembelajaran IPS di kelas.

Mata pelajaran IPS disusun secara sistematis, komprehensif, dan terpadu dalam proses pembelajaran menuju kedewasaan dan keberhasilan dalam kehidupan di masyarakat. Waterwroth (dalam Lasmawan 2010) menyebutkan bahwa tujuan social studies (IPS) adalah untuk mempersiapkan siswa menjadi warga negara yang baik dalam kehidupannya di masyarakat, dimana secara tegas ia mengatakan "to prepare students to be well-functioning citizens in a democratic society". Tujuan pendidikan IPS dikatakan tercapai apabila hasil belajar siswa mengalami perkembangan dan peningkatan serta mampu membentuk tingkah laku yang sesuai dengan tujuan pendidikan IPS untuk menjadi bermakna oleh siswa.

Ada sejumlah fakta yang menunjukkan bahwa kualitas proses pembelajaran dan pencapaian hasil belajar IPS siswa di kelas V SD Kalibukbuk masih rendah, yaitu: (1) Pembelajaran yang dilakukan oleh guru masih terpusat pada "tampilan dan action social" guru di depan kelas, sehingga pola komunikasi instruksional hanya bersifat searah, walaupun sesekali guru telah mencoba melempar pertanyaan di akhir penjelasannya, namun sikap siswa cenderung pasif. (2) Siswa hanya berusaha menghafal apa yang telah diberikan oleh guru selama pembelajaran di kelas, sehingga yang terjadi hanyalah proses "rethinking bukan morethinking" sebagaimana karakteristik pembelajaran IPS pada jenjang pendidikan dasar. (3) Pembelajaran yang dilakukan oleh guru, belum mampu membelajarkan siswa bagaimana mengenali, memecahkan, dan menyikapi masalah sosial 
aktual yang ada di lingkungan sekitar, karena pembelajaran yang dilakukan oleh guru masih terfokus pada pencapaian ketuntasan materi semata. (4) Hasil ulangan harian dan ulangan akhir semester siswa dalam 1 tahun terakhir masih tergolong rendah, yaitu rata-rata berkisar antara 7,4 sampai dengan 7,6 skala 10. Untuk mata pelajaran IPS hal ini masih tergolong rendah, karena standar pencapaian kompetensi konsep secara nasional untuk tahun 2007 adalah 7,80. (5) Siswa belum mampu menggunakan lingkungan sekolah dan masyarakat sebagai sumber belajar. Mereka hanya mengandalkan catatan yang mereka peroleh saat guru menjelaskan materi ajar, sehingga wawasan dan keterampilan sosial siswa sangat rendah. (6) motivasi siswa dalam pembelajaran IPS relatif redah, karena guru belum mampu rnemilih dan mengernbangkan model pembelajaran yang mampu merangsang dan membudayakan siswa untuk belajar. (7) Model pembelajaran yang selama ini dikembangkan oleh guru masih berorientasi pada model ceramah bervariasi, dimana variasinya hanya tanya-jawab dan sesekali penugasan.

Berdasarkan faktor penyebab masalah yang timbul, maka diperlukan suatu penerapan pembelajaran yang membuat pembelajaran menjadi menyenangkan serta hasil belajar yang akan dicapai nantinya benar-benar meningkat dan bermakna bagi siswa. Dalam hal ini penulis mengangkat salah satu model pembelajaran yang cocok dengan pembelajaran IPS saat ini yaitu dengan Model Accelerated Learning berbasis Peta Konsep yang menekankan pada proses penemuan sebuah konsep sehingga muncul motivasi berprestasi pada diri siswa yang berujung pada peningkatan hasil belajar siswa. Hasil belajar yang dimaksud dalam penelitian ini adalah hasil belajar adalah perubahan tingkah laku yang diperoleh dari kegiatan belajar (Sudjana, 2005). Hasil belajar adalah kemampuan aktual yang dapat diukur, yang mencangkup tiga hal yaitu ilmu pengetahuan (kognitif), sikap (afektif) dan keterampilan (psikomotor), berupa nilai yang dicapai siswa sebagai hasil dari proses belajar di sekolah. Dalam penelitian ini terfokus pada satu aspek penilaian yaitu aspek kognitif pada hasil belajar IPS kelas V SD Kalibukbuk. Sedangakan motivasi berprestasi yang dimaksud adalah penekanan pada pencapaian prestasi dan hasrat kita paling dalam untuk mengerakkan serta menuntun kita menuju sasaran, membantu kita mengambil inisyatif dan bertindak sangat efektif dan untuk bertahan menghadapi kegagalan (Goleman, 2003). Dalam penelitian ini motivasi berprestasi ditinjau dari konsep yang diterapkan Suarni (2004) yang memilah ciriciri serta indikator perilaku motivasi berprestasi menjadi lima kajian yang perlu dicermati sebagai berikut, (1) menunjukkan adanya usaha untuk mencapai keberhasilan, (2) berorientasi pada keberhasilan, (3) inovatif, (4) bertanggung jawab, (5) mengantisipasi kegagalan. Secara lebih rinci ciri-ciri danmotivasi berprestasi oleh Suarni (2004) ini dimaknai sebagai berikut. Pertama, adanya usaha untuk mencapai keberhasilan dimaksudkan sebagai perilaku-perilaku individu yang mengarah pada kegiatankegiatan pencapaian prestasi, seperti : menunjukkan aktifitas fisiologis yang lebih tinggi, mengutamakan kinerja daripada hubungan afiliatif, kegigihan. Kedua, kemauan untuk berorientasi pada keberhasilan yang dimaksudkan sebagai sikap sensitivitas terhadap tanda-tanda yang berkaitan dengan peningkatan prestasi, sadar dan realistis, terarah ke masa depan. Ketiga, inovatif adalah mengandung unsur keinginan untuk menemukan sesuatu cara yang lebih baik atau lebih pendek atau lebih efesien ataupun mungkin cara yang berbeda dari sebelumnya untuk menuju suatu keberhasilan. Makna lain yang tergolong juga ke dalam aspek ini adalah keinginan untuk berkompetisi baik dengan prestasi sendiri sebelumnya maupun prestasi orang lain sehingga mendapat umpan balik diri sendiri menjadi salah satu kondisi yang sangat penting. Di samping itu inovatif juga mengandung keinginan untuk suka menghadapi tantangan. Aspek inovatif seperti : menggunakan waktu lebih efisien, tugastugas yang menantang dengan tingkat kesulitan sedang, kebutuhan umpan balik, menghindari rutinitas atau kreativitas, keinginan berkompetisi. Keempat, bertanggungiawab secara pribadi dalam 
menyelesaikan tugas meliputi ciri-ciri kesempurnaan penyelesaian tugas, percaya diri serta tangguh dalam bekerja. Aspek bertanggung jawab meliputi bertanggung jawab secara pribadi, berkonsentrasi pada suatu tugas, kesempurnaan tugas, tangguh dalam bekerja. Kelima, kemampuan individu untuk mengantisipasi kegagalan adalah mengandung unsur kewaspadaan, sadar akan ancaman kegagalan dan kekurangan usaha atau ketelitian dan kecermatan untuk berusaha menanggulang situasi-situasi penghambat pencapaian keberhasilan baik berupa anteseden maupun konsekuensi. Dalam penelitian ini tingkat antisipasi kegagalan yang dimunculkan terdiri dari beberapa kreteria seperti: kewaspadaan, ketelitian atau kecermatan, usaha-usaha penanggulangan atau antisipatif.

Peningkatan hasil belajar dan motivasi berprestasi pada siswa dalam penelitian ini akan ditingkatkan melalui pembelajaran inovatif. Model pembelajaran inovatif abad 21 salah satunya adalah Model Accelerated Learning (Rose and Malcolm, 2002). Model ini sangat relevan karena dalam kegiatan belajar mengajar model ini menginginkan siswa mengalami kegembiraan dalam belajar sehingga pembelajaran lebih bermakna. Kegembiraan yang dimaksud adalah bangkitnya minat dan motivasi siswa dalam belajar, keterlibatan penuh siswa dan menjadikan pembelajaran yang dilakukan bermakna (Meier, 2002). Hal tersebut didukung oleh penelitian sebelumnya yang telah membuktikan keefektifan Model Accelerated Learning dalam proses pembelajaran terhadap hasil belajar oleh Fatnasari (2008).

Penelitian yang dilakukan lebih inovatif dan efektif Model Accelerated Learning dipadukan dengan peta konsep sebagai basis atau dasar dari model yang diterapkan, karena pembelajaran menggunakan peta konsep (concept mapping) merupakan inovasi baru yang penting untuk membantu anak menghasilkan pembelajaran bermakna di dalam kelas. Penerapan pembelajaran peta konsep merupakan salah satu strategi pembelajaran yang inovatif yang menyediakan bantuan visual konkret untuk membantu mengorganisasikan informasi sebelum informasi tersebut dipelajari sehingga siswa mampu merekonstruksi dan mengeksplorasi sendiri pengetahuaannya (Martin dalam Trianto, 2007). Strategi pembelajaran concept mapping atau peta konsep adalah strategi pembelajaran untuk memperlihatkan konsep-konsep dan proposisi-proposisi suatu materi (Suparno. 2001). Penelitian sebelumnya yang telah membuktikan keefektifan peta konsep dibuktikan oleh Danang Setyo Pambudi (2010) yang menyatakan bahwa strategi pembelajaran peta konsep dapat meningkatkan hasil belajar.

Atas dasar yang telah dikemukakan mengenai permasalahan yang ditemukan di SD Kalibukbuk pada siswa kelas V khususnya mata pelajaran IPS, maka peneliti mengadakan penelitian eksperimen dengan judul pengaruh Model Pembelajaran Accelerated Learning berbasis Peta Konsep terhadap motivasi berprestasi dan hasil belajar IPS siswa kelas V SD Kalibukbuk Kecamatan Buleleng Kabupaten Buleleng.

\section{METODE PENELITIAN}

Penelitian ini menggunakan metode penelitian eksperimen, adapun jenis eksperimen pada penelitian ini, yaitu eksperimen semu (quasi eksperiment), dengan pola dasar "The Posttest-Only Control-Group Desain" hal ini dilihat dari subjek eksperimen yang tidak dirandomisasi untuk menentukan sampel guna ditempatkan dalam kelompok eksperimen dan kelompok kontrol. Desain rancangan eksperimen pada penelitian ini menggunakan dua kelompok, yaitu kelompok eksperimen (experiment group) dan kelompok kontrol (control group). Pelaksanaan penelitian diklasifikasi menjadi tiga bagian, yaitu: materi pembelajaran, model pembelajaran dan waktu pelaksanaan. Model pembelajaran pada penelitian ini adalah model accelerated learning berbasis peta konsep, sebagai kelompok eksperimen dan model konvensional sebagai kelompok kontrol. Materi pembelajaran yang dipilih terlebih dahulu dikaji karakteristiknya guna dipadukan pada pembelajaran model accelerated learning berbasis peta konsep, yang kemudian 
dituangkan dalam rencana pelaksanaan pembelajaran (RPP). Populasi dalam penelitian ini adalah semua siswa siswa SD kelas V di SD Kalibukbuk yang berjumlah sebanyak 148 orang. Sampel penelitian ini ditentukan dengan menggunakan teknik random sampling.

Sebelum menetapkan sampel penelitian, terlebih dahulu dilakukan uji kesetaraan pada masing-masing kelas Uji kesetaraan yang dilakukan menggunakan bantuan SPSS 17.0 for windows dengan signifikansi 5\%. Jika angka signifikansi hitung kurang dari 0,05 maka kelas tersebut tidak setara. Sedangkan jika angka signifikansi hitung lebih besar dari 0,05 maka kelas tersebut setara. Berdasarkan hasil uji kesetaraan yang telah dilakukan didapatkan hasil bahwa seluruh siswa SD kelas V di SD Kalibukbuk memiliki kemampuan yang setara. Untuk menentukan kelas eksperimen dan kelas kontrol, peneliti melakukan pengundian terhadap pasangan kelas yang setara untuk digunakan sebagai sampel. Dari hasil pengundian diperoleh SD 4 Kalibukbuk sebagai kelas kontrol dan SD 2 kalibukbuk sebagai kelas eksperimen dengan total sampel dalam penelitian ini sebanyak 74 orang. Variabel bebas dalam penelitian yaitu Model Accelerated Learning berbasis Peta Konsep. Sedangkan variabel terikat dalam penelitian ini yaitu motivasi berprestasi dan hasil belajar IPS siswa.

Data pada penelitian ini ada dua yakni motivasi berprestasi dan hasil belajar siswa. Data mengenai motivasi berprestasi siswa dikumpulkan menggunakan lembar kuesioner dengan 1-5 (skala Likert). Sedangkan data mengenai hasil belajar siswa dikumpulkan dengan menggunakan tes objektif pilihan ganda dengan empat pilihan.

Pada penelitian ini penggunaan instrumen sesuai dengan jenis data yang dicari. Pembuatan instrumen dalam penelitian ini, terlebih dahulu disusun kisi-kisi instrumen. Kisi-kisi hasil belajar disusun dengan berpedoman pada kurikulum yang ada yakni kurikulum KTSP 2006 menyangkut standar kompetensi, kompetensi dasar, aspek materi dan indikatornya. Kisi-kisi instrumen motivasi berprestasi siswa indikatornya diambil dari dimensi motivasi berprestasi yang dikembangkan oleh Suarni (2004) yaitu (1) menunjukkan adanya usaha untuk mencapai keberhasilan, (2) berorientasi pada keberhasilan, (3) inovatif, (4) bertanggung jawab, (5) mengantisipasi kegagalan. Sebelum instrumen digunakan, terlebih dahulu dilakukan expert judgment oleh dua orang pakar guna mendapatkan kualitas tes yang baik. Setelah dilakukan expert judgment maka intrumen akan diujicobakan ke lapangan untuk mengetahui validitas dan reliabilitas instrument tersebut. Dalam penghitungan validitas dan reliabilitas tes digunakan program Microsoft Office Excel.

Hasil penelitian ini dianalisis secara bertahap, yaitu: deskripsi data, uji prasyarat, dan uji hipotesis. Uji prasyarat yang dilakukan yaitu uji normalitas sebaran data, uji homogenitas varians, dan uji antar variabel terikat.

Uji normalitas data dimaksudkan untuk memperlihatkan bahwa data sampel berasal dari populasi yang berdistribusi normal (Candiasa, 2007), sehingga uji hipotesis dapat dilakukan. Uji normalitas data dilakukan pada empat kelompok data, Uji homogenitas dimaksudkan untuk memperlihatkan bahwa dua atau lebih kelompok data sampel berasal dari populasi yang memiliki variansi yang sama (Candiasa, 2007), sedangkan uji korelasi antar variabel terikat dilakukan untuk mengetahui apakah korelasi antar variabel terikat tersebut tinggi atau rendah. Karena, jika korelasi antar variabel terikat tinggi maka variabel terikat tidak dapat dipisahkan, sedangkan jika korelasi antar variabel terikat rendah atau tidak ada korelasi maka variabel terikat dalam penelitian ini dapat dipisahkan.

Hipotesis yang dipakai dalam penelitian ini adalah a) terdapat perbedaan motivasi berprestasi terhadap mata pelajaran IPS antara siswa yang mengikuti Model Accelerated Learning berbasis Peta Konsep dengan siswa yang mengikuti model pembelajaran langsung pada siswa kelas V SD Kalibukbuk, b) terdapat perbedaan hasil belajar siswa yang mengikuti Model Pembelajaran Accelerated Learning berbasis Peta Konsep dengan siswa yang mengikuti Model Konvensional pada mata pelajaran IPS siswa kelas V SD Kalibukbuk, c) terdapat perbedaan motivasi 
berprestasi dan hasil belajar antara siswa yang mengikuti Model Accelerated Learning berbasis Peta Konsep dengan siswa yang mengikuti model konvensional pada siswa kelas V SD Kalibukbuk pada mata pelajaran IPS.

Pengujian hipotesis 1 menyatakan terdapat perbedaan motivasi berprestasi terhadap mata pelajaran IPS antara siswa yang mengikuti model pembelajaran accelerated learning berbasis peta konsep dengan siswa yang mengikuti model pembelajaran langsung pada siswa kelas V SD Kalibukbuk, dan hipotesis 2 menyatakan terdapat perbedaan hasil belajar siswa yang mengikuti model pembelajaran accelerated learning berbasis peta konsep dengan siswa yang mengikuti model konvensional pada mata pelajaran IPS siswa kelas V SD Kalibukbuk dalam penelitian ini menggunakan MANOVA melalui statistik varians ( $\mathrm{F}$ antar), sedangkan hipotesis 3 menyatakan terdapat perbedaan motivasi berprestasi dan hasil belajar antara siswa yang mengikuti model pembelajaran accelerated learning berbasis peta konsep dengan siswa yang mengikuti model konvensional pada siswa kelas V SD Kalibukbuk pada mata pelajaran IPS dilakukan dengan uji $\mathrm{F}$ melalui $M A N O V A$. Untuk menganalisis data dalam penelitian ini digunakan SPSS-17.00 for windows pada signifikansi 0,05 .

\section{HASIL DAN PEMBAHASAN}

Objek dalam penelitian ini adalah motivasi berprestasi dan hasil belajar siswa sebagai hasil perlakuan antara penerapan Model Accelerated Learning berbasis Peta Konsep dan Model Pembelajaran Konvensional: 1) motivasi berprestasi yang dibelajarkan dengan Model Pembelajaran model Accelerated Learning berbasis Peta Konsep dengan rekapitulasi hasil perhitungan mean $=141,58$, median $=140$, modus $=160$, standar deviasi $=21,45$, varians $=459,96$, rentangan skor $=81$, skor minimum $=96$, skor maksimum $=177,2$ ) hasil belajar IPS yang dibelajarkan dengan Model Pembelajaran Model Accelerated Learning berbasis Peta Konsep dengan rekapitulasi hasil perhitungan mean $=26,47$, median $=27$, modus $=27$, standar deviasi $=4,38$, varians $=19,23$, rentangan skor $=15$, skor minimum $=19$, skor maksimum $=34,3$ ) motivasi berprestasi yang dibelajarkan dengan model konvensional dengan rekapitulasi hasil perhitungan mean $=$ 128,71 , median $=128.5$, modus $=106$, standar deviasi $=19,40$, varians $=376,536$, rentangan skor $=82$, skor minimum $=90$, skor maksimum $=172,4)$ hasil belajar IPS yang dibelajarkan dengan model konvensional dengan rekapitulasi hasil perhitungan mean $=$ 22,34 , median $=23$, modus $=23$, standar deviasi $=4,89$, varians $=16,72$, rentangan skor $=16$, skor minimum $=14$, skor maksimum $=30$. Masing-masing dari ke empat distribusi tersebut, disajikan dengan cara menyajikan rata-rata sebagai ukuran sentral, standar deviasi sebagai ukuran penyebaran, tabel frekuensi dan histogram.

Sebaran data Rekapitulasi hasil perhitungan skor keempat variabel tersebut di atas menunjukkan perbandingan yang signifikan antara masing-masing variabel baik dalam rata-rata sebagai ukuran sentral, standar deviasi sebagai ukuran penyebaran tabel frekuensi dan histogram.

Berdasarkan hasil uji prasyarat analisis, untuk uji normalitas sebaran data masingmasing variabel dengan perhitungan berbantuan SPSS 17.00 for windows. Diperoleh statistik Kolmogorov-Smirnov untuk Hasil Pengujian Normalitas Sebaran Data dengan Uji Kolmogorov-Smirnov dan Shapiro-Wilk untuk motivasi berprestasi siswa yang mengikuti model pembelajaran accelerated learning berbasis peta konsep adalah 0,084. Hasil Pengujian Normalitas Sebaran Data dengan Uji KolmogorovSmirnov dan Shapiro-Wilk untuk hasil belajar IPS siswa yang mengikuti model pembelajaran accelerated learning berbasis peta konsep adalah 0,065. Hasil Pengujian Normalitas Sebaran Data dengan Uji Kolmogorov-Smirnov dan Shapiro-Wilk untuk motivasi berprestasi siswa yang mengikuti model pembelajaran konvensional adalah 0,096. Hasil Pengujian Normalitas Sebaran Data dengan Uji Kolmogorov-Smirnov dan Shapiro-Wilk untuk hasil belajar IPS siswa yang mengikuti model pembelajaran konvensional adalah 0,071. Berdasarkan data tersebut di atas Rekapitulasi Hasil Pengujian 
Normalitas Sebaran Data dengan Uji Kolmogorov-Smirnov dan Shapiro-Wilk memiliki angka signifikansi lebih besar dari 0,05 . Maka semua sebaran menurut model pembelajaran berdistribusi normal.

Selanjutnya dilanjutkan dengan Uji homogenitas dilakukan terhadap kelompok data motivasi berprestasi dan hasil belajar IPS siswa baik secara bersama-sama maupun secara sendiri-sendiri. Analisis menggunakan SPSS-17 for windows dengan hasil analisis uji Box' $M$ adalah 0,644 > 0,05, sementara hasil uji Levene's Test untuk Motivasi berprestasi adalah 0.409 dan untuk hasil uji Levene's Test Hasil belajar IPS adalah 0.543 angka signifikansi yang dihasilkan baik secara bersama-sama maupun sendiri-sendiri lebih besar dari 0,05. Dengan demikian dapat disimpulkan bahwa matrik varian-kovarians terhadap variabel motivasi berprestasi dan hasil belajar IPS siswa adalah homogen.

Hasil uji korelasi menunjukkan bahwa data motivasi berprestasi dan hasil belajar IPS siswa yang belajar dengan Model Pembelajaran Accelerated Learning berbasis Peta Konsep mendapatkan harga $\mathrm{r}_{\mathrm{y} 1 \mathrm{y} 2}=0,231$ dan data siswa yang belajar dengan model konvensional mendapatkan harga $r_{\mathrm{y} 1 \mathrm{y} 2}=0,041$ Nilat $\mathrm{r}_{\text {hitung }}<\mathrm{r}_{\text {tabel }}(0,304)$ pada taraf signifikansi 5\%, maka dapat disimpulkan bahwa data motivasi berprestasi dan hasil belajar IPS siswa yang mengikuti Model Pembelajaran Accelerated Learning Berbasis Peta Konsep maupun siswa yang belajar dengan model pembelajaran konvensional tidak berkorelasi.

Hasil uji hipotesis dalam penelitian ini terbukti bahwa: Pertama, motivasi berprestasi siswa yang mengikuti Model Pembelajaran Accelerated Learning berbasis Peta Konsep hasilnya lebih baik daripada motivasi berprestasi siswa yang mengikuti model pembelajaran konvensional. Berdasarkan data hasil analisis multivariat dengan bantuan SPSS 17 for windows diperoleh nilai $\mathrm{F}$ sebesar 7.345, df $=1$, dan Sig $=0,008$. Ini berarti signifikansi lebih kecil dari 0,05 dapat ditarik simpulan bahwa terdapat perbedaan yang signifikan motivasi berprestasi antara siswa yang belajar dengan Model Pembelajaran Accelerated Learning berbasis
Peta Konsep dengan model pembelajaran konvensional.

Berdasarkan data hasil analisis tersebut, secara teoritis dapat dikatakan bahwa penggunaan pembelajaran Accelerated Learning berbasis Peta Konsep lebih baik dan efektif untuk melibatkan motivasi berprestasi siswa dalam proses pembelajaran. Motivasi berprestasi yang dimaksud merupakan motivasi dalam diri siswa untuk meraih prestasi dengan meningkatnya motivasi siswa belajar untuk menuju kebermaknaan dalam belajar. Model Pembelajaran Accelerated Learning berbasis Peta Konsep lebih baik dan efektif untuk melibatkan motivasi berprestasi siswa dalam proses pembelajaran. Model ini memberikan ruang yang cukup untuk siswa mengkonstruksi pengetahuan, mengembangkan kemampuan yang dimiliki, memiliki motivasi untuk belajar dan berusaha.

Temuan dalam penelitian ini sesuai dengan statment yang menunjukkan bahwa motivasi berprestasi menekankan akan pentingnya kebutuhan akan prestasi, karena orang yang berhasil adalah orang yang dapat menyelesaikan sesuatu dan tetap berusaha untuk belajar (Uno, 2007). Hal ini juga sesuai dengan hasil penelitian Atrup (2008) yang melakukan penelitian tentang implementasi Model Accelerated Learning (MAL) dalam upaya meningkatkan motivasi berprestasi dan kemandirian (self-regulation) belajar siswa.

Temuan kedua, penelitian ini secara empiris menunjukkan bahwa hasil belajar IPS siswa yang mengikuti Model Pembelajaran Accelerated Learning berbasis Peta Konsep hasilnya lebih baik daripada hasil belajar IPS siswa yang mengikuti model pembelajaran konvensional. Berdasarkan data hasil penelitian analisis multivariate dengan berbantuan SPSS 13 for windows diperoleh nilai $\mathrm{F}$ sebesar $17.580, \mathrm{df}=1$, dan $\operatorname{sig}=0,000$. Ini berarti nilai sig lebih kecil dari 0,05 dapat ditarik kesimpulan bahwa terdapat perbedaan yang signifikan hasil belajar IPS antara siswa yang mengikuti Model Pembelajaran Accelerated Learning berbasis Peta Konsep dengan siswa yang mengikuti model pembelajaran konvensional.

Pembelajaran yang dikembangkan dengan Model Pembelajaran Accelerated 
Learning berbasis Peta Konsep lebih memungkinkan terjadinya proses pengkonstruksian pengetahuan. Proses pembelajaran akan lebih bermakna bila siswa yang mengkonstruksi pengetahuannya sendiri dan mengalami langsung dari apa yang dipelajarinya. Hal ini sejalan dengan hasil penelitian Fatnasari (2008) dalam penelitiannya menyatakan bahwa model Accelerated Learning dapat meningkatkan hasil belajar IPS dan mampu meningkatkan aspek kognitif, afektif dan psikomotorik.

Temuan ketiga, Hasil analisis MANOVA menunjukkan bahwa harga $F$ hitung untuk Pillae Trace, Wilk Lambda, Hotelling's Trace, Roy's Largest Root dari implementasi Model Pembelajaran Accelerated Learning berbasis Peta Konsep dapat dilihat pada tabel 01. berikut.

Tabel 1. Ringkasan Hasil Analisis Motivasi Berprestasi dan Hasil belajar IPS Siswa dengan

\begin{tabular}{clcc}
\multicolumn{4}{c}{ Manova } \\
\hline Effect & \multicolumn{1}{c}{ Statistik } & F & P \\
\hline Model Pembelajaran & Pillae Trace & $12.006^{\mathrm{a}}$ & .000 \\
& Wilk Lambda & $12.006^{\mathrm{a}}$ & .000 \\
& Hotelling's Trace & $12.006^{\mathrm{a}}$ & .000 \\
& Roy's Largest Root & $12.006^{\mathrm{a}}$ & .000 \\
\hline
\end{tabular}

Hasil analisis MANOVA menunjukkan bahwa harga $\mathrm{F}$ hitung untuk Pillae Trace, Wilk Lambda, Hotelling's Trace, Roy's Largest Root dari implementasi Model Pembelajaran Accelerated Learning berbasis Peta Konsep lebih kecil dari 0,05. Artinya semua nilai Pillae Trace, Wilk Lambda, Hotelling's Trace, Roy's Largest Root signifikan. Dengan demikian, terdapat pengaruh penerapan Model Pembelajaran Accelerated Learning berbasis Peta Konsep terhadap motivasi berprestasi dan hasil belajar IPS secara simultan pada siswa kelas V SD Kalibukbuk Kecamatan Buleleng Kabupaten Buleleng. Hal ini disebabkan karena penerapan Model Pembelajaran Accelerated Learning berbasis Peta Konsep memacu siswa memiliki motivasi berprestasi dalam belajar, karena dengan adanya jalinan motivasi untuk berprestasi yang tinggi akan mempermudah proses pembelajaran yang terjadi sehingga tujuan pembelajaran dapat tercapai dengan baik dan berimplikasi pada hasil belajar yang meningkat.

\section{SIMPULAN DAN SARAN}

Berdasarkan hasil pengujian hipotesis dan pembahasan maka dapat ditarik simpulan sebagai berikut.
Pertama, terdapat perbedaan motivasi berprestasi dalam pembelajaran IPS antara siswa yang mengikuti Model Accelerated Learning berbasis Peta Konsep dengan siswa yang mengikuti model pembelajaran konvensional pada siswa kelas V SD Kalibukbuk Kecamatan Buleleng Kabupaten Buleleng. Motivasi berprestasi siswa yang belajar dengan Model Accelerated Learning berbasis Peta Konsep lebih baik daripada kelompok siswa yang belajar dengan model pembelajaran konvensional.

Kedua, terdapat perbedaan hasil belajar siswa yang mengikuti Model Accelerated Learning berbasis Peta Konsep dengan siswa yang mengikuti model konvensional pada mata pelajaran IPS siswa kelas V SD Kalibukbuk Kecamatan Buleleng Kabupaten Buleleng. Hasil belajar siswa yang belajar dengan Model Accelerated Learning berbasis Peta Konsep lebih baik daripada kelompok siswa yang belajar dengan model pembelajaran konvensional.

Ketiga, terdapat perbedaan motivasi berprestasi dan hasil belajar IPS secara simultan antara siswa yang mengikuti Model Accelerated Learning berbasis Peta Konsep dengan siswa yang mengikuti model konvensional pada siswa kelas V SD Kalibukbuk Kecamatan Buleleng Kabupaten 
Buleleng. Motivasi berprestasi dan hasil belajar IPS yang belajar dengan Model Accelerated Learning berbasis Peta Konsep lebih baik daripada kelompok siswa yang belajar dengan model pembelajaran konvensional.

Berdasarkan berdasarkan temuan yang telah dipaparkan, maka dapat diajukan beberapa saran guna meningkatkan kualitas pembelajaran IPS ke depan.

Pertama Hasil penelitian menunjukkan bahwa siswa yang belajar dengan Model Accelerated Learning berbasis Peta Konsep secara signifikan memiliki motivasi berprestasi yang tinggi daripada siswa yang mengikuti model konvensional. Untuk itu, model ini hendaknya diperkenalkan dan dikembangkan kepada pendidik guna menciptakan suasana yang menyenangkan namun tetap fokus. Kedua, Hasil penelitian ini menunjukkan bahwa siswa yang belajar dengan Model Accelerated Learning berbasis Peta Konsep secara signifikan memiliki hasil belajar IPS yang tinggi daripada siswa yang mengikuti model konvensional. Oleh karena itu, para pendidik disarankan menggunakan Model Accelerated Learning berbasis Peta Konsep dalam pembelajaran di sekolah untuk meningkatkan hasil belajar IPS. Ketiga, Pendidik hendaknya mempelajari setiap detail Model Accelerated Learning berbasis Peta Konsep baik dari segi isi maupun konteks, guna mempermudah siswa dalam belajar baik dari cara mencatat seperti peta konsep, meditasi di awal pembelajaran untuk memfokuskan pikiran siswa, bekerjasama dengan siswa untuk memperindah kelas guna mengembangkan rasa memiliki sampai pada penyajian materi yang dirancang sedemikian rupa, sehingga pendidik maupun siswa merasa nyaman dalam proses pembelajaran. Keempat, Mengingat keterbatasan waktu dan pokok bahasan yang digunakan dalam penelitian ini, maka disarankan kepada peneliti lain, agar melaksanakan penelitian sejenis dengan pemilihan materi yang berbeda dan waktu yang lebih lama untuk mendapatkan gambaran yang lebih meyakinkan mengenai Model Accelerated Learning berbasis Peta Konsep terhadap motivasi berprestasi dan hasil belajar IPS. Kelima, Untuk penyempurnaan penelitian ini, disarankan kepada peneliti lain untuk mengadakan penelitian lanjut dengan melibatkan variabelvariabel lain, misalnya keterampilan hidup, kecerdasan interpersonal dan lain sebagainya.

\section{DAFTAR RUJUKAN}

Atrup. 2008. "Pengembangan Program Pembelajaran Berdasarkan Model Accelerated Learning (MAL) Sains Kelas V Sekolah Dasar". Tersedia pada http://docs.google.com/viewer? $\mathrm{a}=\mathrm{v} \& \mathrm{q}=$ cache:3IHBYzy jXVcJ: pas ca. um.ac.id/wp-content/uploads /2010/Abstrak\%25202008/S3-1/1-u mp ul\%2520 abst rak\%2520TEP-S31.doc+penerapan+Model+ Accel erated +learning+di+S D \&l=id\&gl =id\&pid=bl \&srcid=ADGEES g5muk Tjlvnwkn (diakses tanggal 15 Maret 2011).

Candiasa, I Made. 2007. Statistik Multivariat Petunjuk Analisis dengan SPSS, Program Pasca Sarjana Universitas Pendidikan Ganesha Singaraja.

Fatnasari, Elisa. 2008. "Implementasi Accelerated Learning dalam Upaya Meningkatkan Hasil Belajar Matematika (PTK Pembelajaran Matematika di Kelas IV SD N Cemara 2 No. 13 Surakarta)". Tersedia pada http://etd.eprints.ums.ac.id/501/ (diakses tanggal 15 Maret 2011).

Goleman. 2003. Kecerdasan Emosi untuk Mencapai Puncak Prestasi. Jakarta: PT Gramedia Pustaka Utama.

Lasmawan, Wayan 2010. Menelisik Pendidikan IPS dalam Perspektif Kontekstual-Empiris. Singaraja: Mediakom Indonesia Press Bali

Meier, Dave. 2002. The Accelerated Learning Handbook: Panduan Kreatif \& Efektif Merancang Program Pendidikan dan Penelitian. Bandung: Kaifa.

Rose, Colin \& Malcolm J. Nicholi. 2002. Accelerated Learning for the 21st Century. Jakarta: Nuansa. 
Setyo Pambudi, Danang. 2010. "Penerapan Strategi Pembelajaran Peta Konsep terhadap Hasil Belajar Biologi Siswa SMP Negeri 3 Bayat Kabupaten Klaten Tahun Ajaran 2009/2010". Tersedia pada http://beduatsuko.blogspot.com/2009/ 02/skripsi-Strategi-Pembelajaran-PetaKonsep.html (diakses tanggal 20 juni 2012).

Suarni, N. K. 2004. "Meningkatkan Motivasi Berprestasi Siswa Sekolah Menengah Umum di Bali dengan Strategi Pengelolaan Diri Model Yates". Disertasi. Yogyakarta. PPS UGM Yogyakarta.

Sudjana. 2005. Strategi Pembelajaran. Bandung : Falah Production.

Trianto. 2007. Model-model Pembelajaran Inovatif Berorientasi Kontruktivistik. Surabaya: Prestasi Pustaka.

Uno, Hamzah B. 2007. Teori Motivasi dan Pengukurannya Analisis di Bidang Pendidikan. Jakarta: Bumi Aksara. 